\title{
From North Carolina to KwaZulu Natal: World Library Partnership
}

\author{
by Donna Nixon
}

n July of 2003 most nights found me huddled in my sleeping bag, reluctant to leave its warmth to rush down the hall to the dormitory bathroom. It was the tail-end of winter in Mpumalanga Province in the Republic of South Africa, and I was there as a volunteer with the World Library Partnership (WLP), a North Carolina non-profit organization devoted to promoting global understanding through support of community libraries in South Africa and other developing countries.

The World Library Partnership is an organization, seemingly powered by the sheer will of its director and assistant director: the gentle, thoughtful and resourceful Laura Wendell; and the boisterous, gregarious, and boundlessly enthusiastic Maggie Hite. But the truth is that it is powered by the determination of many committed people from the communities that stand to benefit, the United States, and several other countries. Laura Wendell, the organization's founder, was inspired to form World Library Partnership during a stint in the Peace Corp, during which the local Togo community recruited her to help them create a literacy program and a community library.

That was in 1991. Wendell returned to the United States determined to work with other communities in developing nations, to assist them in bringing libraries and literacy to their people. The core mission for WLP evolved from Wendell's initial attempts to share her books and magazines with her friends in Togo, and from lessons learned from other programs. One major lesson she learned is that materials for these community libraries need to be language appropriate and relevant to the communities they serve. It was very difficult for Wendell to share with her friends the books and magazines she received from the United States because her reading material was in English, a language that her Togo friends did not speak. What they really needed was reading material in their own languages and also material that was actually relevant to their communities.

\section{Book Dumping}

WLP welcomes donations of time, resources, and money, but is very vocal against the idea of used-book donations. ${ }^{1}$ Ask WLP Assistant Director Maggie Hite about "book dumping" and you will get an earful. Many book donation programs, though well-intentioned, engage in "book dumping," a practice of shipping old used books that burden rather than assist communities. Why is WLP so adamant against international book donation? Picture yourself as a school librarian in an impoverished, rural North Carolina community. The 
community has little or no money for books, so the shelves are sparsely populated. A woman in France reads an article about your library's need and decides to gather and send used books. She manages to collect a large carton of used books from neighbors and friends. The problems begin when she tries to ship them. Shipping books or any heavy cargo internationally is quite expensive. She spends several weeks raising money to ship the books off. Finally, the books arrive in North Carolina by cargo plane and have customs fees of $\$ 300$ attached.

How useful are those books? Let's assume that you, the local librarian, are able to have the customs charges waived (we can dream, can't we?). You then have to transport the books. You rent a truck and haul the carton of books to your library. Opening the carton you discover ... what? Yes, the books are mainly in French, they are outdated, and they are not age-appropriate for your students. In egregious cases, the books donated are outdated engineering manuals or instruction booklets for technology like microwave ovens to which the communities have no access. Consider also how dangerous some outdated books can be that recommend use of techniques or chemical agents, perhaps in agriculture, that have since been shown to be hazardous. This illustrates some of the problems inherent in "book dumping."

There are many reasons WLP shuns book donations. Sending books to another country or region is expensive. Both sender and recipient incur shipping costs, and customs charges are usually levied against the receiver. Rarely is the recipient library able to pay these charges, and it does not know beforehand whether the items are going to be at all helpful. In the end it is usually cheaper to buy books from local publishers. Book donations from another country also damage the local book trade. Local writers, publishers, and booksellers are unable to sustain the local publishing industry if there is no market for their products and services. Libraries are an important player in the industry both because they are buyers and because their patrons are likely to buy books after they have gained an interest in them through the library.

The WLP also discourages book donations because local language materials for developing countries are not available in the United States. Though people in many countries speak English as a second or additional language, they often find it easier and more helpful to read material, especially difficult material, in their native languages. A love of reading is more easily fostered when obstacles such as language barriers are not thrown in someone's path. In addition, one is more likely to be inspired to read when one can relate to the characters and situations. Books written and published by local people are more likely to establish that connection. Finally, in order to communicate effectively, regardless of what other languages they may study, people must be competent in reading and writing their native languages. That goal is hard to achieve in the absence of books and other reading materials in those languages.

Allowing the local libraries to choose what materials they receive, based on their communities' needs, empowers the libraries and communities with which WLP partners. If you were starting a library in your community, you would attempt to assess the needs of that community, and then choose materials for that library accordingly. Some remote person in China could decide what he or she thinks would be the best materials for your library, but he or she would be very unlikely to pick a collection that is what your community either wants or needs most. The local librarian, working with a committee of community members, is better-equipped and situated to evaluate his or her library's needs.

Some potential donors, however, have been hard to convince. One with whom I recently spoke insisted that surely "the classics" would be helpful in any library. Another was sure that any elementary school library in a developing country would want Harry Potter books. That may be true, but it is not necessarily the case. Some religious communities here in North Carolina 
would strongly object to, and would be deeply offended by, a donation of Harry Potter books because of their depiction of sorcery and magic. Whatever your definition of "the classics" encompasses, it may not be the same as the next person's, and it is best to let those most familiar with the communities involved decide what literary works hold that distinction. Certainly, it would be hard for me to name twenty major South African writers of ancient or modern times, but that does not mean that they are any less significant than ones we revere in the Western world. Consider, for example, the South African writer J.M. Cotzee, who just recently won first the Booker and then the Pulitzer Prize for his works of essay and fiction. ${ }^{2}$ Had he not won those prizes, many of us might not have ever heard of him, but that would not make his works any less valuable. For that reason, it is better that libraries select their own materials.

Finally, it is important to remember that U.S. materials are not written for African audiences or audiences in other developing countries. Differences in culture, context, and many other things that affect perception make a huge difference in how library material is received. For example, if you ran a library in Saudi Arabia, you would probably not

Differences in culture, context, and many other things that affect perception make a huge difference in how library material is received. openly display copies of the U.S. version of Cosmopolitan magazine, with its often scantily clad women, since in Saudi Arabian society that type of physical exposure of a woman's body is frowned upon. ${ }^{3} \mathrm{~A}$ Saudi library is also not likely to be receptive to books by Danielle Steel or other best-selling authors that often describe sexual situations. These are unsubtle examples, but if you have ever gone abroad, you know that less obvious things we take for granted as acceptable are not always acceptable elsewhere. For instance, in some European communities touching fruits and vegetables on grocery produce tables seems to garner the same reaction as if you had visited the bathroom and then served food without washing your hands. Even the most well-intentioned act can have negative implications that hinder rather than help. ${ }^{4}$

So, how does WLP help communities? WLP uses several methods to assist community libraries. It provides training material and training programs, "book certificate" programs, volunteer programs, and a resource database. ${ }^{5}$ To achieve its mission WLP has at various times partnered with the Ford Foundation, the Riecken Foundation, and university and other community service programs. WLP has assisted libraries in Zimbabwe, South Africa, and Honduras.

One thing that makes WLP so amazing and unique among library assistance organizations is that it has had a global impact inverse to its actual financial and human resources. It operates on a shoestring budget and generally has only two or three full-time staff members at any time. Maggie Hite and one part-time assistant, Bally Monchonyane, are currently the entire South Africa office staff. Nevertheless, WLP has been creative in finding ways to continue to bring resources to communities. From yard-sale fundraisers to partnerships with university and community service programs, to work with large charitable foundations, WLP has been truly resourceful.

\section{Inform the World Program}

I was one of thirty librarian volunteers from the United States, Canada, and Kenya who were fortunate to work with WLP in South Africa in the summer of 2001. WLP recruited volunteers through postings to librarian listservs, presentations at library conferences and schools, and word of mouth. All but one of the volunteers were professional librarians. All agreed to give four weeks of their time and to fundraise $\$ 2,000$ to work with librarians in poor rural South African communities. Our one non-librarian volunteer was a computer consultant. He went along to help set up computers and Internet connections, where available, and help train people to use computer re- 
sources.

That summer we worked with school libraries primarily in two different provinces: KwaZulu-Natal and Mpumalanga Province. While the U.S. is in summer, South Africa is in winter. Luckily, the winters are comparatively mild. Though fairly chilly at night, it warmed up to the high 50s and 60s (Fahrenheit) during the day. Our volunteer experiences were all different, and all rewarding. Each of us was paired with another WLP volunteer and worked with a host teacher-librarian. Some librarians worked in truly rural conditions where there was no electricity and no indoor plumbing. Some of us worked in poor townships that were more suburban than rural. Our living arrangements varied. Some of us shared dormitory accommodations that were generously donated by a local mining company, while most got the opportunity to stay in the homes of our wonderfully hospitable host teacher-librarians.

All of us were prepared by WLP to work under challenging conditions. South Africa is an emerging nation burdened with many historical issues related to wealth distribution, race relations, and public health. It has a very diverse population, including descendants of Dutch, German, and English settlers, Asians, Blacks of dozens of different tribes, and mixed-race people. In the decades before 1994, the White minority government engaged in systematic, crushing oppression of the Black majority, and, to a lesser extent, the country's Asian and mixed-race populations. ${ }^{6}$ Many of the Asian and mixed-race or colored people aligned themselves as "Black" South Africans during the struggle for equality.

The human rights violations against "Black" South Africans paralleled much of what African Americans and Native Americans endured in the United States. But the abuses in South Africa were taking place in modern times, producing civil unrest that lasted from the 1950s until the government was finally handed over to democratic majority rule in $1994 .{ }^{7}$ Under the Apartheid regime the government forcibly removed Blacks, Asians, and mixed-race people into "townships" and "homelands" on the poorest quality land. ${ }^{8}$ The government passed laws limiting Blacks to enough education just to serve the White population, banning Blacks from professional schools and universities. ${ }^{9}$ Blacks were further denied access to decent housing, health care, clean water, and many other basic services including the major public libraries. ${ }^{10}$ Every library had to be designated for a particular race. One could not use a library designated for another race, and the major public libraries were designated for Whites only. The government created separate poor and inadequately stocked libraries for Blacks. ${ }^{11}$ At the same time, the White population enjoyed all the services and conveniences of modern Western society. The legacy of Apartheid has left most black South Africans in segregated poverty that the new government has few resources to alleviate.

WLP screened the volunteers to insure that we could be flexible, creative, open-minded, and sensitive to these communities. We prepared by studying material prepared or recommended by WLP and former volunteers, including WLP's publication Libraries for All: How to Start and Run a Small Library (1998), and Nelson Mandela's autobiographical account of the political struggle, Long Walk to Freedom (1994). ${ }^{12}$ Through a listserv and Internet discussion board set up by WLP we introduced ourselves to one another and exchanged advice and questions about fundraising and about our trip. We met one another and our host librarians for the first time at Hotel 224 in Johannesburg, South Africa, where we, both host and visiting librarians, went through orientation together. Our hosts were honored to have us there. Rarely do their communities have Western visitors, and rarer still is the Western visitor that is there to help. They treated us like visiting dignitaries. We, in turn, were awed by the determination, strength, optimism, and resourcefulness of our hosts and communities, and often shamed by our monolingualism in the face of the ability of nearly every South 
African man, woman, and child to speak four or more different languages. ${ }^{13}$

What we saw in the schools was what one would expect to see in a poor rural school in a developing country: overcrowding, lack of supplies, few or no textbooks, no computers or other audiovisual electronic aids (except perhaps one television for the entire school), lack of extracurricular activities, overworked teachers, and high rates of absenteeism and dropout. What was surprising was the lack of despair and how much teaching and learning went on, despite the dearth of resources.

I was paired with a cataloging librarian from Texas (originally from the Netherlands), and assigned to Zacheus Malaza Secondary School, a high school in Mpumalanga Province. The school had total enrollment of 1,535 students, with 43 educators. The classes were crammed into 22 classrooms with about 60 students or more in each class. The student/ teacher ratio, as per government requirements, is actually supposed to be 1:45. Despite the teachers' monumental courseloads, each school had a teacher, who voluntarily took on the added responsibility of running the library, without any additional release time or pay. With the help of a couple of students who were part of the small student library committee, the librarian at Zacheus Malaza struggled to manage the library and make it available to students. We didn't perform any miracles in our brief four weeks there, but we made a big impact on the communities and they made a big impact on us in several ways.

\section{Impact of the Program}

We made a big impact simply by showing up. The fact that we recognized their struggle and took the time to go to their communities to help them gave them a much-needed boost. Our visit also prompted the Department of Education and a local mining company to get moving on getting resources to the school that had been promised for months. The Department of Education nudged a book company to deliver the books for which they had already been paid, and the department got some basic supplies to us so that we could process books and get them on the shelves. The mining company at last delivered the much-worn, salvage-grade computers that they had promised for months. We also helped the librarian recognize that artifacts from their South African cultures and from student achievements were appropriate decorations to liven up the library. We helped the teacherlibrarian catalog, organize, and assign subject headings to their small collection. We helped train the student library volunteers to check in and out and shelve books. We helped a few of the students and teachers gain a minimal comfort level using the computers. Finally, we donated $\$ 500$ and worked with our teacher-librarian to use that money to select the

We learned how to work with local librarians to gauge their communities' needs, and learned to resist imposing our own values on them. books and other material they most needed for their library.

The impact we had on students, who looked to us for mentoring, cannot be overestimated. Several students came to me for advice and guidance about writing, careers, and college, and I encouraged them strongly to pursue education at both the high school and college levels. When I returned to the United States, I continued to correspond with one gifted writer who hoped to pursue a college degree.

What did the experience do for us volunteers? Those of you who have spent time in another culture know that working within that culture changes your outlook and assumptions. Often, you come to realize that the way that you have done things all your life is not "the one right way." You may not be ready to embrace a completely different way of doing things, but it does occur to you that there are other alternatives. The most important things this experience taught us was to open up to new ideas and to be more creative - to do more with less. We made book pockets and check-out cards from construction paper and made protective book covers from sheets of transparent adhesive 
paper. We learned to conserve resources as much as possible. We could have brought a truckload of supplies from the United States, but eventually those supplies would run out and the community would be back where it started. So we had to think creatively of ways to use resources to which the community would still have access. We learned how to work with local librarians to gauge their communities' needs, and learned to resist imposing our own values on them. We also learned a little bit about other cultures. I was a welcomed guest at several community and family rituals: weddings, funerals, cultural celebrations, and family society meetings.

Are the communities we worked with a little better off due to our visit? I think and hope so. Am I a better librarian for having gone? You bet. Would I do it again? In a heartbeat-all-weather sleeping bag in hand, of course.

\section{References}

1 The World Library Partnership,"Book Donation," available at http:// worldlibraries.org/bookdonation/, accessed 10 Nov. 2003.

2 Alan Riding, "Coetzee, Writer of Apartheid as Belak Morror, Wins Nobel Prise," New York Times, 3 Oct. 2003: A1. See also, Michiko Kakutani, "Chronicling Life Perched on a Volcan's Edge as Change Erupts," New York Times, 3 Oct. 2003: A6.

3 "Barbie Deemed Threat to Saudi Morality," AP News Service, 9 Sept. 2003. See also, Patrick Bishop, "Women Lead a Quiet Revolution within Islam," Daily Telegraph (London), 22 July 2003.

${ }^{4}$ A recent attempt to transplant a Cuban literacy program into Venezuela, complete with Cuban advisers, and audiovisual and print materials, created a major controversy and was opposed by Venezuelan teachers' unions and activists who viewed the material as intended to indoctrinate Venezuelan poor communities with Cuban ideology. See "Venezuela: Cuban Literacy Programme Stirs Up Controversy," BBC Monitoring International Reports, 11 July 2003: Latin Section.

${ }^{5}$ Book-certificate programs provide a specific amount of money to each library to purchase books. In 2001, we donated approximately $\$ 500$ to each library with which WLP worked in South Africa.

${ }^{6}$ See the UNESCO publication Apartheid, detailing how racism was institutionalized to permeate every aspect of the lives of South Africans. UNESCO, Apartheid (Paris: UNESCO, 1967).

7 The nation's first non-racial election took place in April 1994 and President Mandela's inauguration as president took place the next month. See, Nelson Mandela, Long Walk to Freedom (Boston: Little, Brown, 1994), 531-40.

8 A number of laws restricted Blacks, who represented over $90 \%$ of the population, to living in designated areas limited to $13 \%$ of the land in South Africa. Those laws included the Group Areas Act, the Natives (Urban Area) Consolidations Act, the Asiatic Land Tenure and Indian Representation Act, and the Native Administration Act. See, Apartheid, 13-20. See also, United Nations Department of Public Information, The United Nations and Apartheid, 1948-1994 (New York: United Nations, 1994), 9-10. See, Apartheid, page 17, for information about land distribution.

9 See, Apartheid, 31-33, discussing South Africa's Bantu Education Act of 1953 and the Indians' Education Act of 1967.

10 Apartheid, 160-65.

${ }^{11}$ Ibid.

${ }^{12}$ Laura Wendell, Libraries for All! How to Start and Run a Basic Library (Paris: UNESCO, 1998); and Mandela, Long Walk to Freedom.

13 South Africa has eleven official languages. See, Basildon Peta, "South African Begins to Promote 11 Official Languages," The Independent (London), 23 Sept. 2003: 13. People generally need to speak more than one language to communicate well with others. 